\title{
LA ANARQUÍA Y LAS FACCIONES TIENEN MÚLTIPLES CABEZAS. LA ALEGORÍA DE LA MEDUSA Y LA HIDRA EN EL LENGUAJE DECIMONÓNICO RIOPLATENSE
}

Facundo Nanni(a)

ANARCHY AND FACTIONS HAVE MULTIPLE HEADS. THE

ALLEGORY TO MEDUSA AND THE HYDRA IN THE NINETEENTH-

CENTURY LANGUAGE IN RÍO DE LA PLATA

A ANARQUia E AS FACÇÕES TêM MÚLTIPLAS CABEÇAS. A ALEGORIA DA MEDUSA E DA HIDRA NA LINGUAGEM DO SÉCULO XIX RIO-PLATENSE

Fecha de recepción: 5 de agosto del 2020

Fecha de aprobación: 5 de octubre del 2020

Disponible en línea: 9 de diciembre del 2020

Sugerencia de citación:

Nanni, F. (2021). La anarquía y las facciones tienen múltiples cabezas. La alegoría de la Medusa y la Hidra en el lenguaje decimonónico rioplatense. Razón Crítica, 10, 61-92. https://doi.org/10.21789/25007807.1702

(a) Facundo Nanni

Doctor en Ciencias Sociales (orientación Historia), Conicet-Universidad Nacional de Tucumán Miembro de la Junta de Estudios Históricos de Tucumán, Argentina

facundosnanni@yahoo.com.ar 


\section{R E S U M E N}

En forma similar a lo que había ocurrido en la península ibérica con la asimilación de Napoleón Bonaparte y el monstruo bíblico de múltiples cabezas, la cultura rioplatense de las primeras décadas del siglo xIX se valió de antiguas imágenes — clásicas y católicas_-, para otorgar una figura deslegitimante a sus adversarios. El objetivo del presente trabajo, producto del cruce entre historiografía y análisis del discurso, es analizar el uso de este lenguaje clásico en la cultura política rioplatense de principios del siglo xIX, por vía de textos como la Metamorfosis del romano Ovidio, o el General Estoria de Alfonso x "el Sabio". Los publicistas decimonónicos rioplatenses pusieron en circulación la metáfora de la anarquía y las facciones en términos de regeneración permanente de sus cabezas, instaurando así una suerte de pedagogía política: era conveniente cortar de raíz a los elementos contrarios, emulando el carácter heroico de Perseo y Hércules en los mitos de la Medusa y la Hidra de Lerna. Un abordaje a una temática poco transitada de esta naturaleza, se inserta en un corpus de trabajos que pretenden observar la forma en la que los propios actores sociales rioplatenses dieron sentido e inteligibilidad a los cambios ocurridos en las primeras décadas decimonónicas.

PALABRAS CLAVE: facciones; imagen; lenguajes políticos; Medusa; siglo XIX 


\section{A B S T R A C T}

Similar to what occurred in the Iberian Peninsula with the assimilation of Napoleon Bonaparte as the multi-headed biblical monster, cultural manifestations in Río de la Plata during the first decades of the XIX century adopted the use of ancient images —classical and Catholic — to bestow a delegitimizing figure upon the adversaries of this region. As a result of a merge between historiography and discourse analysis, this work seeks to scrutinize the use of classic language features in the political culture of Río de la Plata region at the beginning of the xix century through texts such as Metamorphosis, by the Roman poet Ovid, or General Estoria, by Alfonso x "the wise." xix century publicists from Río de la Plata put into circulation the metaphor of anarchy and its factions in terms of a permanent regeneration of their heads, thus establishing a kind of political pedagogy where it was convenient to root out the opposing elements, emulating the heroic character of Perseus and Hercules in the ancient myths of Medusa and the Lernaean Hydra. An approach to this scarcely addressed subject is inserted in a corpus of works that try to observe the way in which social actors at Río de la Plata gave meaning and intelligibility to the changes that occurred in this region during the first decades of the XIX century.

\section{KEYWORDS: Factions; image; political languages; Medusa; XIX century.}

\section{R E S U M O}

Assim como o que ocorreu na Península Ibérica com a assimilação de Napoleão Bonaparte e o monstro bíblico de múltiplas cabeças, a cultura rio-platense das primeiras décadas do século xix se utilizou de antigas imagens —clássicas e católicas- para dar uma figura deslegitimante a seus adversários. O objetivo deste trabalho, produto do cruzamento entre historiografia e análise do discurso, é analisar o uso dessa linguagem clássica na cultura política rio-platense de princípios do século xix, mediante textos como Metamorfoses do romano Ovídio ou A General Estoria de Alfonso x, o "sábio". Os publicitários do século xıx rio-platenses colocaram em circulação a metáfora da anarquia e das facções em termos de regeneração permanente de suas cabeças, instaurando assim um tipo de pedagogia política: era conveniente cortar pela raiz os elementos contrários, emulando o caráter heroico de Perseu e Hércules nos mitos da Medusa e da Hidra de Lerna. Uma abordagem de uma temática pouco visitada dessa natureza se insere em um corpus de trabalhos que pretendem observar a forma na qual os próprios atores sociais rio-platenses deram sentido e inteligibilidade às mudanças ocorridas nas primeiras décadas do referido século. 


\section{N T R O D U C C I Ó N}

Tomando como recorte a las provincias rioplatenses durante las primeras décadas del siglo xıx, y en diálogo con una dimensión atlántica, el trabajo observa de qué manera las élites rioplatenses utilizaron imágenes clásicas para referir a sus fraccionamientos, a la resolución de las guerras de independencia y a los problemas derivados de la organización conjunta del territorio. Se analizará el uso de la regeneración de las cabezas en fragmentos discursivos de publicistas, eclesiásticos y hombres de armas de aquellas provincias que alcanzaron un orden constitucional hacia 1853; un recurso estilístico y alegórico muy habitual y aún no explorado en la historiografía, trazando vínculos con los crecientes análisis que han puesto a los lenguajes políticos en una dimensión analítica central (Goldman, 2008; Palti, 2007; Myers, 1995; Wasserman, 2019). Con dicha línea de estudios se comparte la necesidad de observar los conceptos o lenguajes como realidades que no son inmutables, ni de significado lineal/atemporal. Por esta razón, se buscará observar la forma en la que los propios actores sociales dieron sentido e inteligibilidad a los vertiginosos cambios políticos ocurridos desde la ruptura con la corona española, hasta la organización constitucional argentina, tomando un periodo que presenta cierta unidad temática e historiográfica. Para ubicar una investigación acerca de la recurrencia de este motivo alegórico que remitía a la Hidra y a la Medusa, en tanto mitos que aludían al desorden de las cabezas y al orden de aniquilarlas de un hachazo, se inicia con la observación del uso que tuvieron estas imágenes verbales en tierras americanas, de la mano de estudios que han analizado estas alegorías como expresiones destinadas a quitar entidad a todo adversario o facción que disputase el poder (Gaune, 2018). 
Luego de hacer una observación de estos mitos en su antigüedad clásica y en su expresión atlántica desde el siglo xviII, se examinarán los ejemplos extraídos de las diferentes fuentes analizadas (sermones, arengas militares y fragmentos de la prensa decimonónica), ubicando a la alegoría de las cabezas múltiples en ejemplos que la contextualizan en la Buenos Aires decimonónica y a su vez, en provincias distantes del puerto, en donde también circularon las clásicas alegorías en estas primeras décadas de una centuria de agitadas transformaciones. Aunque se verán excepciones, los monstruos de múltiples cabezas fueron una imagen sugerente para dar inteligibilidad a cambiantes adversarios, en un esquema binario en el cual el sujeto enunciador se arrogaba un lugar heroico: Hércules sí se trataba del mito de la Hidra de la cueva de Lerna, y Perseo sí se trataba del mito de Medusa. Al reponer los contextos de producción, se observará la funcionalidad específica de estas alegorías, sosteniendo que las antiguas imágenes mediterráneas tuvieron un fácil entrecruzamiento con el lenguaje bíblico, particularmente, por la figuración réptil del demonio en el Apocalipsis. Para entender esta confluencia de discursos, serán fundamentales los antecedentes investigativos sobre el uso de tópicos antiguos en los inicios del proceso revolucionario rioplatense (Peire, 2000; Di-Stefano, 2003).

Se analizará de qué manera la ductilidad de estas figuraciones en un escenario - diferente al de las sociedades mediterráneas-, se explica por el poder sintetizador de un universo cultural que gozaba de cierta circulación, y permitía comprimir sentidos y formas de comprensión de la realidad, dotándolos de una figuración visual y narrativa potente conocida entre las élites. Constituían un modo de obtener una definición, sino clara, al menos sugerente respecto a cómo resolver el problema endémico de los enfrentamientos. En efecto, los propios grupos en el poder consideraban que a los elementos contrarios al orden había que "cortarlos de raíz", como habían hecho Hércules con la Hidra de la cueva de Lerna y Perseo contra Medusa. Más allá de la elasticidad o plasticidad de toda leyenda, la ramificación de las cabezas versus el hacha como elemento unitario, favorecía la creación de narrativas que alentaban la reducción de la pluralidad en la unidad. Diagnóstico de una situación (proliferación de grupos amenazantes), y al mismo tiempo, sugerencia de una solución basada en erradicarlas de plano, la metáfora clásica parecía una caja de Pandora con fuerza narrativa para un periodo que se presentaba a ambos lados del atlántico, como un torrente vertiginoso. 


\section{LOS MONSTRUOS MULTIFORMES Y SU GIRCULACIÓN ATLÁNTICA. SIGLOS XVIII Y XIX}

La imagen de las cabezas múltiples había sido una construcción visual habitual en la antigüedad griega, en las polis se apelaba a la fascinación de esta evocación en las multitudes a través del drama teatral, la épica y una variada cultura material. No se trataba entonces solo de palabras, sino de soportes físicos que llevaban estampado el peligro del desorden, en civilizaciones que introdujeron una prolífica discusión sobre las formas, y en dónde lo múltiple corporizaba la idea de la desmesura (hybris). De hecho, lo híbrido, palabra que deriva precisamente de estos conceptos, remitía a figuras cuya fealdad consistía en que sus partes aparecían desnaturalizadas, ajenas al orden del Olimpo (Bartra, 1982; Campbell, 1988; Elíade, 1988). La referencia a la multiplicidad no tenía en el mundo clásico un sentido específicamente político, pero su vaguedad conceptual permitió una reapropiación desde distintas coyunturas históricas, particularmente durante el ciclo de revoluciones del mundo atlántico (1775-1825).

Con una amplitud de variantes en el registro oral, escrito y visual (podía ser representada como cabezas monstruosas o como una mujer bella), la imagen polimorfa que había logrado mayor éxito en el vulgo griego era la que protagonizaba el mito de las Gorgonas, tres hermanas -Medusa, Esteno y Euríale-, de mirada petrificante. La versión recogida por el poeta romano Ovidio (43 a. C.-17 d. C.) fue de gran vigencia y circulación, en particular sus relatos reunidos en Las Metamorfosis (8 d. C.). Allí realizó una traducción latina de la leyenda, agregando elementos que se hicieron célebres como la explicación del origen del monstruo por los conflictos entre Medusa y Atenea, quien castigó a la primera por su vínculo amoroso con Poseidón, quitándole su forma humana. En esta versión aparecían otros detalles referidos a las claves del triunfo de Perseo sobre la mujer-monstruo: utilizó las "sandalias aladas" de Hermes, fue guiado por la propia Atenea deseosa de venganza, portó el "casco de invisibilidad" de Hades, y observó a la bestia desde su escudo para evitar la petrificación.

Una segunda fuente para agregar en este corpus fue la General Estoria de Alfonso X “el Sabio” (1221-1284), fundamentada en la versión ovidiana, pero con elementos cristiano-medievales (Morín, 1999; Ramón-Solans, 2017). Estas versiones romanas y medievales permitieron recuperar en un largo ciclo las pretéritas figuras del inframundo griego, reeditando sus 
Figura 1. Peter Paul Rubens (ca. 1617-18)

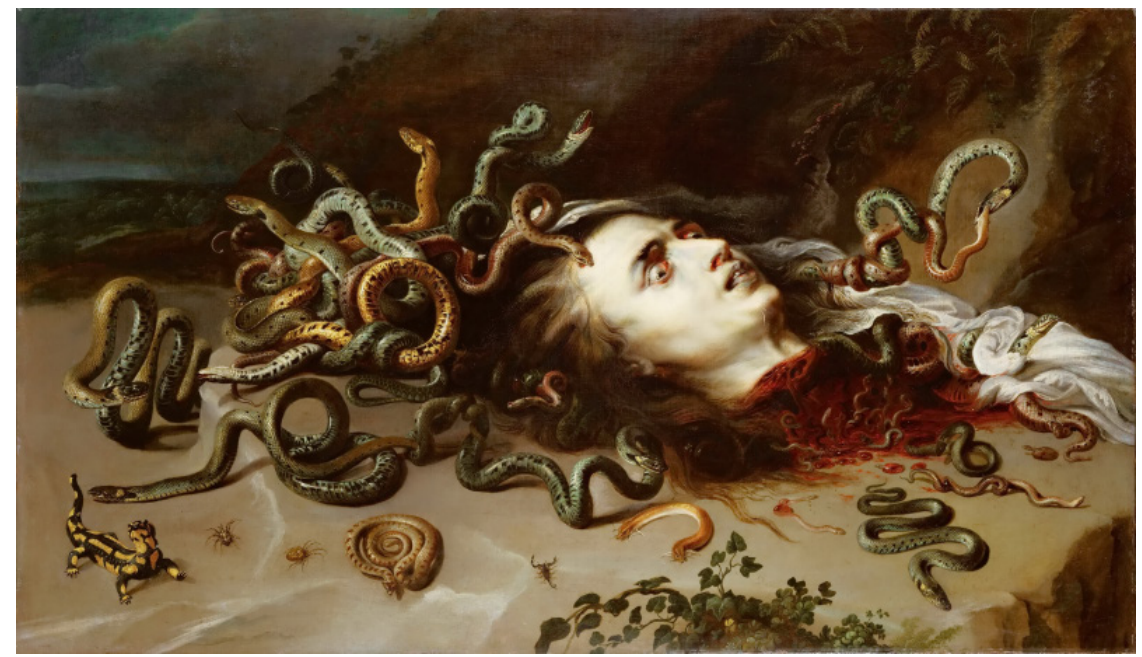

Fuente: Kunsthistorisches Museum Viena.

significados. Sin embargo, no aparecía ni en Ovidio, ni en la interpretación medieval de Alfonso, un uso específicamente político del mito de Medusa, utilización intencionada que las investigaciones han registrado con más claridad en las monarquías europeas desde el siglo xviıI, extendiéndose a sus colonias americanas.

En este trabajo se revisará el itinerario alegórico de las múltiples cabezas, sosteniendo el diálogo con investigaciones que han mostrado el uso de otras alegorías clásicas en la construcción de los poderes monárquicos de los siglos XviI y xviıI, siendo todavía necesaria una integración en el corpus historiográfico. Por ejemplo, la vieja imagen de las columnas de Hércules y su relación con la expansión marítima, fue parte central de la estrategia iconográfica de las monarquías europeas, convertida en el sello personal de Carlos V (Vignolo, 2012; Sanfuentes, 2016). De hecho, para los letrados de las cortes monárquicas, habituados a una formación grecolatina, el triunfo de Hércules contra variados monstruos era una metáfora frecuente para representar al poder, incluyendo su triunfo frente a la Hidra de múltiples cabezas. Entre la realeza inglesa, Guillermo III y posteriormente Jorge I, utilizaron a menudo símbolos referidos al mencionado héroe clásico.

Por vía del dominio de las monarquías europeas, la imagen y sus significados ingresaron rápidamente en las colonias americanas. En las tierras de Surinam, controladas por el Reino Unido, y más adelante por la monarquía holandesa, una rebelión de esclavos del siglo XviıI 
motivó a que el gobernador J. J. Mauritius (1742-1751), mencionara la necesidad de emular a Hércules y destruir la Hidra (Rediker \& Linebaugh, 2000). Luego, en el contexto de la represión de las fuerzas británicas contra la llamada Bussa's rebellion (1816), las fuerzas militares de la corona sostuvieron la necesidad de evitar que la población africana se viera revolucionada por las ideas anti-esclavistas del líder negro Bussa, pretendiendo evitar a la monarquía británica que se expandiera este fenómeno al que llamaron The hydra rebellion (Beckles, 1984).

Tal como se observa en dichos ejemplos de amplia geografía atlántica, en forma similar al uso que tenían las columnas de Hércules o el águila imperial, el triunfo frente a la Hidra funcionaba bien como metáfora monárquica de poder, y constituía un ariete más dentro de la propaganda de las potencias ultramarinas. Estos elementos icónicos parecían funcionar como parte del más integrador mito del imperio universal, idea persistente en la tradición occidental-católica (Vignolo, 2012).

El mencionado uso de la imagen de las cabezas múltiples y su posterior control por parte del poder, no era privativo del Caribe anglosajón. En las distintas regiones españolas, fueron frecuentes durante la invasión napoleónica los sermones que advertían los peligros del "monstruo de la libertad francesa", cuyo aspecto se asimilaba al de un dragón de múltiples cabezas "muy cercano o pariente del llamado en el Apocalipsis Dracus Magnus" (Ramón-Solans, 2017, p. 474). Circulaban una serie de cuentos orales que sostenían las similitudes entre Bonaparte y el

Figura 2. Michelangelo Caravaggio (1597)

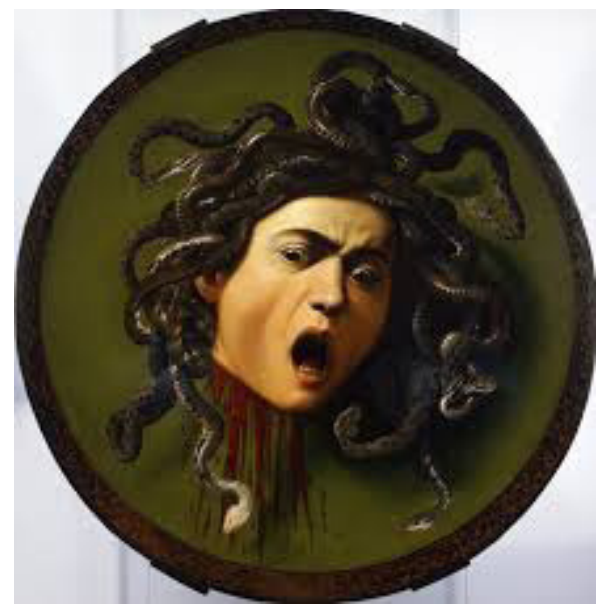

Fuente: M Galería degli Uffizi. 
monstruo bíblico, basados en curiosas asociaciones, como la coincidencia de haber surgido del océano, o apelando a juegos de palabras entre Napoleón y Apolión, ángel que lideraba las langostas del Apocalipsis (Ramón-Solans, 2017).

Dentro de su formulación griega, el mito de las Gorgonas, y en general toda forma múltiple, solía ser una referencia de aspectos negativos (pero abstractos) como el horror, el desorden y la inmoralidad. En sentido cifrado, podían ser eficaces para entender el cosmos —incluida la dimensión política-, pero no eran un elemento de la disputa entre facciones, ni referían a algún líder, operación que comenzará a realizarse en el espacio atlántico a partir del ciclo de revoluciones y su consecuente resemantización de lenguajes.

Esta politización de alegorías se advierte ya en la Ilustración, como es el caso de Voltaire (1694-1778) en El siglo de Luis XVI (1751). En el marco de su análisis sobre la política expansiva francesa, el publicista y pensador parisino celebró la victoria contra las tropas españolas en Girona (1694) concluyendo que: "Les Français, vainqueurs de tous côtés, combattaient dans les alliés un Hydre toujours renaissante"1 (Voltaire, 1751, p. 184). Sin embargo, la politización de imágenes no se aplicaba tan solo como significante de la expansión imperial. Por ejemplo, Jean-Jacques Rousseau (1712-1778) utilizó las cabezas múltiples contra la propiedad privada, uno de los arietes de su pensamiento. La parcelación de la tierra se asemejaba en su obra a la Hidra en tanto monstruo "devorante", difícil de combatir porque tendía siempre a esconder su cabeza (Rousseau, 1762, p. 184). Distintos aspectos de los mitos de la Medusa y la Hidra, incluso confundidos, eran utilizados a favor de la teorización política, aprovechando elementos de alta carga narrativa como la reproducción del mal, la fuerza del héroe, o el carácter huidizo de los monstruos².

\footnotetext{
1 "Los franceses, victoriosos en todos lados, combatieron en los aliados a una Hidra que siempre renace".

2 La reiteración de partes físicas, particularmente la cabeza, aparecía no solo en la Medusa y sus hermanas, sino en una pluralidad de mitos griegos, destacando la mayoría de los monstruos que Hércules tuvo que vencer en sus 12 trabajos, entre ellos, la Hidra de la cueva de Lerna. El monstruo de la Hidra fue un tropo muy usado en el discurso político de las élites rioplatenses, alternando y a menudo confundiendo su uso con la leyenda de la Medusa. La Hidra, que constituía el segundo trabajo del héroe, era una bestia hija del gigante Tifón, hermana de otros seres compuestos como el Cancerbero, la Quimera, la Esfinge, y el León de Nemea.
} 


\section{LAS CABEZAS MÚLTIPLES EN EL TERRITORIO RIOPLATENSE: SU CONNIVENCIA CON EL DISCURSO CATÓLICO}

En el caso rioplatense es elocuente la forma en la que estas alegorías sirvieron dentro del cambiante juego de facciones. Al contener una suerte de enseñanza sobre cómo vencer a las criaturas que amenazaban la paz social, tuvieron una fuerza narrativa para elaborar un discurso moralizante, principalmente en ámbitos que anhelaban reemplazar el lenguaje coloquial por preciosismos que dieran una legitimidad letrada. Estas imágenes que perderían su ductilidad en el siglo xx, tras la irrupción de una cultura científica y racionalista ${ }^{3}$, fueron muy transitadas por las cúpulas decimonónicas.

No es fácil determinar por qué la aparición de esas figuras en tierras rioplatenses es más identificable desde la década de 1820 y durante el largo periodo en el que el gobernador de Buenos Aires, Juan Manuel de Rosas, dominó sobre las provincias rioplatenses (1829-1852). La ausencia de referencias a la Medusa en hombres clave de la década de 1810 como Mariano Moreno, Bernardo de Monteagudo, o la Gaceta de Buenos Aires, puede vincularse con la necesidad de utilizar una pedagogía política más contundente en tiempos de guerra, diferenciándose de recursos literarios que podían ser emparentados con la tradición literaria de la monarquía hispánica, aunque sí fueron usadas las alegorías de las cabezas múltiples en la década de 1810 por hombres como el sacerdote riojano, Pedro Ignacio Castro Barros. La vigencia de las figuras clásicas y cristianas en la cultura decimonónica del ex Virreinato del Río de la Plata, ha sido abordada, entre otros, por Roberto Di Stefano (2003), quien ha ponderado el caudal simbólico que otorgaba "la apelación al imaginario republicano de la antigüedad clásica” (p. 201).

Ambas cajas de Pandora, es decir, el imaginario clásico y el eclesiástico, se entrelazaban en el uso de motivos visuales similares, uno

3 Si bien durante el siglo xx hubo, y aún subsisten, variadas alusiones a la Medusa y a la Hidra, desde el arte y la cultura de masas, su despliegue es ampliamente inferior al que tuvo en centurias anteriores. Como excepciones, la modernidad racionalista dedicó un interés considerable a la imagen de la reproducción de cabezas de serpiente, destacándose el análisis de Sigmund Freud en Das Medusenhaupt (1922), en el cual desarrolla el horror a la castración, así como las evocaciones del mismo personaje por medio de artistas de aquel siglo como Paul Klee, Pablo Picasso y Auguste Rodin. 
de ellos basado en la aparición horrorosa de partes animales o de partes humanas desencajadas, propiciando la reflexión sobre la relación entre lo múltiple y lo uno. Por otra parte, entroncaban bien con el capítulo 12 del Apocalipsis que anunciaba la llegada de un demoníaco dragón rojo con siete cabezas, similar a los monstruos acuáticos de la antigüedad clásica.

En efecto, durante la década de 1820 una serie de letrados eclesiásticos en oposición a las reformas fomentadas por el ministro Bernardino Rivadavia, expresaron su desacuerdo valiéndose de imágenes bíblicas. El mencionado Castro Barros, presbítero que cargaba con su experiencia en el Soberano Congreso que declaró la independencia en Tucumán, sostenía que ante los peligros del "monstruo de la anarquía" había que concretar un acercamiento a la Santa Sede, como medida sanadora ante los desórdenes del año 1820. Aquel presbítero se expresaba con un lenguaje temible, buscando impresionar a la feligresía de las variadas provincias en las que actuó, para lo cual apelaba frecuentemente a la imagen de la "Bestia apocalíptica", también conocida como Leopardo, dejando una impronta memorable por sus enseñanzas en su comprovinciano Facundo Quiroga. Las poderosas figuraciones a las cabezas múltiples permitían alertar contra la Ilustración francesa, ya que en opinión de Castro Barros la cúpula directiva cercana a Rivadavia, se había inspirado en estas ideas peligrosas para el orden católico en su interpretación. Así, apelando a antiguos temores, sostenía en su sermón que el filosofismo anticristiano era un peligro para el orden católico y familiar, e insistía en que algunas ideas de la ilustración francesa abrían las puertas al "Leopardo apocalíptico" (Di Stefano, 2003, p. 216) ${ }^{4}$. La coyuntura de caída del poder central, en la que cada provincia rioplatense se entregaba a sus fantasmas, causaría también resquemor en otras provincias alejadas del puerto, pero conectadas con la cultura occidental atlántica. Por tanto, se seleccionaron nuevos usos alegóricos de la regeneración de cabezas, cuya utilización comenzó a registrar mayores ejemplos en la década de 1820, en un contexto de fragmentación política en el que parecía resultar potente este arsenal de imágenes que referían a la tensión entre lo uno y lo múltiple.

4 Las palabras del padre Castro Barros recuerdan el siguiente pasaje bíblico: "Vi cómo salía del mar una bestia, que tenía diez cuernos y siete cabezas, y sobre los cuernos diez diademas, y sobre las cabezas nombres de blasfemia. Era la bestia que yo vi semejante a una pantera, y sus pies eran como de oso, y su boca como la boca de un león" (Di Stefano, 2003, p. 216). 


\section{TUCUMÁN, 1820: EL MONSTRUO DE LA OPOSICIÓN}

Tanto en la vertiente bíblica como grecolatina, la visualización de monstruos permitió erigir un discurso moralizante de lo político en tierras del sur americano. Su uso también fue frecuente en la ciudad de San Miguel de Tucumán, periférica respecto al puerto de Buenos Aires, pero medular para la guerra en tanto sede principal del Ejército Auxiliar del Perú entre 1812 y 1819. La mención reiterativa a las cabezas múltiples permitió dar rienda suelta a una narrativa que sostenía el carácter pecaminoso de quienes intentaban oponerse a los gobernantes. Durante la experiencia autonomista de la República de Tucumán del gobernador Bernabé Aráoz (1820-1821), su tío y principal socio político, Pedro Miguel Aráoz (1759-1832), se apoyó en este cajón de sastre de alegorías. El letrado sexagenario también contaba con el trasfondo de haber sido congresal en la etapa tucumana del Soberano Congreso (1816), como el ya mencionado Castro Barros, usando referencias visuales que mostraban una común formación. De sus estudios teológicos en el Real Colegio de San Carlos de Buenos Aires, continuados en la Universidad de Córdoba, el tucumano Aráoz había aprendido a reutilizar este arsenal. Se valió de los recursos de estilo, principalmente durante la década de 1820, momento en el que su sobrino directo atravesaba un tiempo accidentado en la gobernabilidad de dicha provincia (Nanni, 2017). Además de gozar del púlpito como ámbito privilegiado para influir sobre las mentalidades, Pedro Miguel Aráoz encontró un espacio de pedagogía que el bernabeísmo supo inaugurar en la provincia: fue redactor del primer periódico tucumano distribuido en los pueblos de Catamarca y Santiago, hasta que lograron su autonomía. Es decir que, al observar la circulación de estas alegorías en el espacio riojano, en los pueblos del norte y en la zona portuaria rioplatense, se encuentran elementos todavía parciales pero tendientes a mostrar la circulación de las mencionadas alegorías y lenguajes políticos.

Espacios como el periódico El Tucumano Imparcial (1820-1821), sumados al púlpito y a otros ámbitos de encuentro social, fueron fundamentales para desplegar una narrativa visual y católica, destinada a dotar de inteligibilidad al contexto posterior a la caída del Directorio y del poder central. La referencia a la existencia de "imágenes verbales" se entiende en función de que gran parte de los recursos utilizados, partían de un lenguaje figurado y rico en imágenes, que no se veían, 
pero evocaban aquel sentido ocular. En sociedades anteriores a las técnicas de reproducción masiva, las propias nociones de "imagen” y de "idea" se entrelazaban, y el primer término no remitía necesariamente a aquellos fenómenos exteriores y ópticos, siendo más común en el mundo eclesiástico ubicar a ambos como de naturaleza interna. El propio concepto de idea proviene del verbo griego "ver", favoreciendo aquella imbricación, y corresponde con la idea platónica de que el pensamiento es una impresión en la mente de la realidad exterior (Mitchell, 2016; Godicheau \& León, 2015) ${ }^{5}$.

La tendencia a usar referencias visuales fue habitual en el sacerdote Aráoz, que buscaba recursos discursivos para deslegitimar a los adversarios del bernabeísmo, ya fueran españoles o miembros de facciones disidentes. Para lograr efectos en los lectores del periódico, se esmeraba en una escritura con referencias permanentes a lo abominable y a los espacios de la geografía mítica grecolatina:

Este es el horrendo cuadro que con deshonor y sangre ha trazado la anarquía, tal la boca del Averno donde al tocar la cima del Olimpo nos han precipitado pasiones viles y feroces, y si por desgracia ellas siguen adelante, un vandalaje general, un feudalismo feroz, un exterminio de la moral y buen sentido, el enervamiento funesto de la esclavitud y barbarie nos arrastrarán atados, y pondrán en las fauces de las hidras españolas (Aráoz, 14 de octubre de 1820, pp. 3-4. El destacado es nuestro).

Su lenguaje sobrecargado posibilitaba criticar el estado de desunión en las provincias desde 1820, y por eso la "anarquía” le recordaba al portal del inframundo (Averno). Este espacio del cosmos que condensaba "pasiones viles y feroces", permitía referir al posible fracaso de la revolución si eran derrotados por las "hidras españolas”, que fácilmente podían reproducir sus cabezas si las provincias continuaban divididas. En la ductilidad del lenguaje figurado, los adversarios del bernabeísmo podían ser tropas realistas en un proceso revolucionario particularmente expuesto en la frontera septentrional, o bien, enemigos más cercanos de la

5 La articulación entre imagen (imago) y concepto o idea, fue motivo de diferentes teorizaciones. Dicho aspecto, que excede al presente trabajo, se encuentra en un arco de discusiones que van desde Platón a la teoría figurativa de Wittgenstein, pasando por la idea de "impresiones" presente en David Hume. A diferencia del idioma español, la lengua inglesa desdobla images para las imágenes mentales, reservando pictures para imágenes con soporte material (pinturas, esculturas, fotografías, prensa gráfica, etcétera). 
provincia y sus inmediaciones, que precisamente fueron quienes dieron fin a la efímera República de Tucumán.

Las imágenes mostraban los peligros del fin del orden institucional que había aglutinado a las provincias declaradas en 1816 independientes de España y de toda metrópoli. Este descenso era representado como un hundimiento a la "Boca del Averno", es decir, al cráter que daba entrada al acuoso inframundo, o también, una caída hacia las "fauces" de la Hidra española.

Tal como se viene diciendo, las imágenes clásicas tenían una larga vigencia en el espacio atlántico, y circulaban en conjunto con textos y hombres que se desplazaban, particularmente en el continente americano durante las guerras de independencia. Por ejemplo, el flujo de hombres revolucionarios a ambos lados de la Cordillera llevó consigo estas alegorías, no siendo Aráoz el único en reproducirlas. En Tucumán la misma imprenta traída por Manuel Belgrano en 1817, fue un espacio para la prosa del general Francisco Pinto, quién luego llegaría a ser presidente una vez constituido Chile como estado-nación. Casado con una mujer tucumana, el militar oriundo de Santiago de Chile fue el redactor de un periódico de tipo militar impreso en Tucumán, llamado Diario Militar del Ejército Auxiliar del Perú, que en su n. 5 advertía sobre el "monstruo de la anarquía", y en el siguiente se refería a los "réptiles devoradores de la envidia". La selección de ejemplos, permite observar la migración y traslado territorial de las alegorías. En este caso, los puentes lingüísticos, militares y políticos a ambos lados de la Cordillera crearon dinámicas, relaciones y circulaciones humanas que ayudan a entender cómo migraban los lenguajes políticos ${ }^{6}$.

Retomando al sacerdote Aráoz, hay que recordar que por su formación en los estudios clásicos, conocía la aproximación que Aristóteles desplegó en su Poética (335 a. C.), en la cual la metaphora era el "traslado de un nombre de una cosa a otra cosa, del género a la especie o de la especie al género" (Fernández-Ramos, 2015, p. 11). Por los programas de sus estudios en la Universidad de Córdoba, tenía acceso a la "función poética" y a la "función retórica" que Aristóteles asignaba a dichos artilugios (Martínez-Paz, 1940). La cultura clásica, incluida la retórica romana de Cicerón en De Oratoria (55 a. C), así como la Ars Poética (s.f.) de Horacio,

6 Además del mencionado general Francisco Pinto, y su participación en el Diario del Ejército Auxiliador del Perú, las alegorías monstruosas se observan en otros hombres que actuaron en la revolución. El sacerdote Julián Navarro se movió en sentido inverso a Pinto: desde el territorio rioplatense al trasandino. En los sermones que pronunció a ambos lados de los Andes, utilizaba la referencia a la Hidra y la necesidad de cortarla de raíz. Véase Carranza (1907). 
exaltaban la capacidad expansiva de los recursos de estilo, pero advertían sobre los excesos, teniendo en cuenta que la metáfora desdoblaba la interpretación en dos niveles. El propio Platón, quien la había considerado una demostración de inteligencia, sostenía que podía implicar un “juego de palabras" que se alejara de la verdad.

Además de los libros y estudios, el sacerdote tucumano tenía inspiraciones más pictóricas. Circulaban en el Tucumán tardo-colonial de su niñez, óleos que representaban a monstruos con el afán por corporizar la idea del pecado. De este modo, en una ciudad que honraba al arcángel Miguel, Príncipe de la Milicia Celestial, el publicista tucumano contaba con una cultura visual limitada pero estimulante, en la cual existían representaciones del santo que venció al diablo/dragón. La figura armada de San Miguel, que posee estudiadas vinculaciones con la leyenda de San Jorge y el dragón de origen romano, había dado lugar a los primeros cuadros que circulaban entre el espacio alto-peruano y la ciudad de San Miguel de Tucumán (Terán, 2008) ${ }^{7}$.

Ahora bien, retomando las alegorías de Pedro Miguel Aráoz, en su prosa es evidente el enérgico llamado de atención contra la disolución del orden central, por ello, sus alegorías no eran solo de estilo sino que cumplían una función persuasiva. El temor al crecimiento de opositores y en términos generales la preocupación por el caos social, se evocaban con la dramática mención al inframundo del Avernus y los lugares y personajes de aquel mundo acuático, repleto de ofidios y seres múltiples, que generaban un efecto poético pero también un sentido argumentativo de vinculación con la importancia del orden al interior de la provincia y de la relación de pactos con los pueblos rioplatenses. Como contraparte al inframundo, la metáfora parecía sugerir un elemento positivo: las provincias podían asumir una momentánea autonomía relativa, pero debían mantener una base de unión. Si el ejército realista era figurado como un monstruo mitológico, las unidades provinciales debían unirse para erigirse triunfadoras, como lo había realizado el héroe Perseo.

Además, la apelación a la mitología griega, helenística y romana, oficiaba como puente cultural, que permitía dotar de un corpus de

7 En la ciudad de San Miguel de Tucumán circulaban distintos objetos referidos al arcángel que daba nombre a la ciudad, cercanos al universo visual del sacerdote Pedro Miguel Aráoz. Uno de los primeros cuadros locales es el denominado "Alférez Real Felipe García de Valdez". En dicha pintura del siglo xvii se retrataba al encomendero, Alférez Real, y protagonista del traslado de la ciudad Felipe García de Valdez, junto a una imagen del arcángel San Miguel aplastando a un dragón. 
semblanzas conocidas, fácilmente adaptables a una finalidad política. Si el citado Cicerón había insistido en su obra De Oratoria en el enigmático "efecto decoroso" que la metáfora lograba, la Edad Media había continuado esa exploración de la palabra mediante la idea de la exégesis religiosa, ya que en definitiva, el completo cosmos era un "libro de metáforas" de divina creación (Blumenberg, 2000) ${ }^{8}$.

\section{LA MEDUSA Y EL MUNDO DE LOS OFIDIOS. EL SACERDOTE TUCUMANO INSISTE EN SU ARCÓN DE IMÁGENES}

Parte del encanto dramático del Hades griego era su naturaleza indómita, ubicado como un terreno inferior a la tierra, habitado por seres temibles como Cerbero, de triple cabeza; o más amigables como el anciano balsero Caronte, que trasladaba las almas por el río Aqueronte. La geografía mitológica de pasadizos acuáticos permitía dotar de imágenes fuertes los anuncios, de allí la insistencia de los publicistas en su traslado al discurso político. El carácter de castigo a las bajas pasiones que implicaba el inframundo, facilitaba al redactor tucumano la denuncia de la ambición de los opositores al bernabeísmo, vinculados con los limítrofes gobiernos de Martín Miguel de Güemes (Salta), y Juan Felipe Ibarra (Santiago del Estero). En esta retórica de dualidades, el carácter pestilente de los opositores y de los españoles, que aún estaban en batalla, eran contrastados con los intereses pretendidamente imparciales del grupo gobernante.

Mediante el lenguaje dicotómico del periódico El Tucumano Imparcial, los grupos adversarios eran privados de toda legitimidad ya que según el sexagenario letrado recurrían a la "pestilente profesión de las facciones y partidos”. Fiel a una concepción típicamente decimonónica, los grupos adversos eran calificados como ambiciosos y, por tanto, parte de un mundo de hedor e imágenes desagradables. La narrativa de tipo cósmica, le permitía al publicista ubicar del lado heroico al hacendado Bernabé Aráoz, presentado en el periódico como un héroe. Volviendo su rostro hacia los mitos, la solución que ofrecía el publicista se inspiraba en la técnica de

8 La alusión a personajes antiguos brindaba autoridad moral e intelectual. En El Tucumano Imparcial aparecen personajes de la Atenas clásica, como Platón y Plutarco, y referencias romanas, como las menciones a Lucio Quincio, Cicerón, y a la leyenda de la Roca Tarpeya. Por su parte, El Monitor Federal, de tiempos rosistas, publicaba en su portada una cita de Cicerón. 
Perseo frente a la Medusa, esto es, cortarla de raíz teniendo en cuenta que el desorden político tendía a su reproducción: "Siendo los mismos desastrosos sucesos los que agotan su figurada ramificación [...] fue descubierto su complicado nido con toda la maniobra y vil trabazón de sus factores [...] hemos intentado sofocar esa venenosa sierpe que nos arrastra a tantos males" (Aráoz, 14 de octubre de 1820, pp. 3-4).

La referencia peyorativa hacia las facciones es permanente en su retórica, valiéndose no solo de Perseo, sino del gran Hércules y su fuerza muscular, para alegóricamente indicar la forma de desprenderse de los aspirantes. Al menos en el exiguo círculo de lectores del periódico, todos parecían tener familiaridad con los obstáculos que Hércules (Heracles, su nombre griego) había enfrentado para vencer a la Hidra venenosa en sus 12 trabajos. La propia facción bernabeísta, que ostentaba un pasado de glorias por su participación en batallas como la de Tucumán (1812), era conocida como la "facción heroica", adjetivo positivo que en boca de sus detractores podía reformularse como "héroes de mierda", forma de difamación que aparece con frecuencia en el epistolario entre el fray porteño Cayetano Rodríguez y el tucumano José Agustín Molina9

Si el sacerdote podía reivindicar para su grupo el carácter heroico, otros héroes clásicos servían de referencia como el gigante Anteo. En las creencias griegas, este súper-hombre que dominaba una isla cercana al Estrecho de Gibraltar, resultaba una amenaza en función de sus exorbitantes dimensiones. Como parte de las ramificaciones familiares típicas de la mitología griega, el coloso Anteo debía su poder a la herencia de su madre, la diosa Gea, la cual le otorgaba atributos si tocaba el suelo. Hércules nuevamente fue el único capaz de vencerlo, utilizando una estrategia diferente a la desplegada contra las Hidras venenosas. Esta vez apretó al engendro hasta asfixiarlo, sin que acariciara el suelo, evitando así que recibiera el poder de su madre Tierra. El gobernador Bernabé Aráoz debía tener esa mezcla de fuerza física con inteligencia frente a sus opositores:

9 Pese a formar parte de facciones enfrentadas, Molina utilizaba metáforas similares a las del sacerdote Aráoz, que incluían el tópico de la Hidra multiforme, véase Cayetano (2008). Una de las décimas del sacerdote Molina se llama La Anarquía (Zeballos, 1902, p. 99):

Allá en los campos funestos,

donde alzando la frente impía se hace aún fuerte la anarquía

con sus miserables restos.

Volad pues allá Guerreros

marchad a cortarlo apriesa

y del monstruo la cabeza

caiga prontamente al veros. 
Es de absoluta necesidad armarse contra ellos sin permitirle jamás tregua. [...] Sobrepónganse con firmeza a las facciones y empeñen todo su celo en aniquilarlas; si ellas avanzan y el espíritu de partido quisiera reanimarse, estréchelos el gobierno entre sus vigorosos brazos y los sofocaría como al Anteo de la fábula (Aráoz, 1820, pp. 3-4. El destacado es nuestro).

De esta forma, más allá de usar la imagen de las múltiples cabezas o del coloso Anteo, parecía que los adversarios podían derrotarse si se tomaban las correspondientes referencias a los héroes antiguos. En todo caso, frente al otro político decimonónico, había que actuar mezclando la astucia y la fuerza. ¿La abstracción y complejidad de estas metáforas podían servir a la táctica de un bernabeísmo ya muy golpeado? En este escenario enrarecido, las metáforas pretenciosas de Pedro Miguel Aráoz parecían un ejercicio estéril, que no lograría evitar la caída de la República de Tucumán. Más allá de los límites de las publicaciones rioplatenses, el tono moral y la referencia mixta entre lo grecolatino y lo católico, fue una fórmula de poderío visual que atrajo también a otros letrados particularmente numerosos en Buenos Aires.

\section{EL LENGUAJE MORAL-POLÍTICO EN EL "PADRE" GASTAÑEDA}

Por su carácter norteño, el sacerdote Pedro Miguel Aráoz, puede resultar un publicista menos abordado que Francisco de Paula Castañeda (1776-1832), sin embargo, se rescata la potencialidad de integrar estudios que muestren los niveles de vinculación entre el puerto y otros espacios rioplatenses, en este caso, en función de la pregunta por las imágenes discursivas. Ambos hombres conjugaron la actuación en el espacio eclesiástico, con el uso de sofisticados recursos literarios y periodísticos, en un marco de creciente expansión de los ámbitos de acción del clero regular y secular (Di Stefano, 2004; Ayrolo, 2007). Abordado desde un enfoque biográfico que destaca su acción política, y también su perfil contestatario, el fraile Castañeda ha sido actualmente rescatado por la historiografía en facetas nuevas, tal como su interés por crear una incipiente esfera de la opinión pública (Herrero, 2012, 2020; Baltar, 2014).

Con origen de impronta notable y nacido en la Buenos Aires colonial, el polemista se inició en la orden franciscana de La Recoleta, completó estudios en la ciudad de Córdoba y retornó a su ciudad natal en los inicios 
del siglo XIX. Tuvo álgida participación en las invasiones inglesas donde aparecieron sus panegíricos, que en las tres primeras décadas le llevaron a figurar en el nuevo siglo en más de veinte periódicos.

El sugerente fraile anclaba su cultura en el mundo del Antiguo Régimen y en la defensa de la moral católica, no incompatible con su apoyo al movimiento revolucionario. Incorporaba un conocimiento de géneros que mezclaba a gusto el teatro, las fábulas, el lenguaje oral y los sermones, entre otras influencias que formaban parte de una cultura española permeada por la oralidad. El franciscano porteño, poseedor de una creatividad literaria expresada en neologismos e ironías, incorporaba ciertos planteos ilustrados, pero con reservas frente a la vertiente francesa. Destaca en su obra una polémica sobre el lenguaje adecuado para escribir dentro de la prensa. En esta discusión, se defendía sobre acusaciones de excesos, sosteniendo que en el afán por ilustrar a los jóvenes era conveniente valerse "de la ironía, de la sátira, del sarcasmo, y de todo estilo malo o bueno" (Herrero, 2018, p. 22).

El cariz de acusación directa de su estilo, se desplegó desde la primera década revolucionaria, asumiendo una función más clara hacia 1820, mismo año clave en el que escribía desde tierras tucumanas Pedro Miguel Aráoz. En aquel año bisagra conocido por sus contemporáneos como la “Anarquía de 1820", Francisco de Paula Castañeda desplegó sus talentos, aunque tres años después sería expulsado de Buenos Aires, acusado por el entorno de Bernardino Rivadavia de abusos en la libertad de expresión. Si bien son relativamente conocidos los incidentes de su expulsión (1823), y su paso por diferentes provincias rioplatenses, este texto se detiene en el uso de las figuras grecolatinas. Tras el desenlace de la Batalla de Cepeda (1820), y con la entrada a Buenos Aires de las tropas federales de Estanislao López y Francisco Ramírez, el letrado franciscano lanzó simultáneamente El Despertador Teo-Filantrópico Místico Político (1820-1822) y el Desengañador Gauchi-Político (1820-1822), este último, con un extenso subtítulo que recordaba las sátiras hispánicas: Federi-montonero, chacuacooriental, choti-protector, y puti-republicador de todos los hombres de bien, que viven y mueren descuidados en el siglo diecinueve de nuestra era cristiana.

El Desengañador tuvo 27 ediciones y una serie de notables innovaciones. Utilizó neologismos para sus adversarios, identificados con las tropas entrerrianas y santafecinas, pero también con el federalismo porteño en un contexto agitado (Ternavasio, 2004; Polastrelli, 2017; Herrero, 1999). Sus sofisticadas agresiones se concentraron en actores políticos a quienes identificó con singulares términos: puti-republicador 
o federi-montonero. Los primeros gobernadores de orientación federal de Buenos Aires fueron muy agredidos en sus alegorías, como el caso de los gobernadores Manuel de Sarratea (1774-1849) y Miguel Estanislao Soler (1783-1849), llamados por él "Franklin y Washington". A los caudillos Francisco Ramírez (1786-1821) y Estanislao López (1786-1838) los rubricaba como "gauchos" o como "chacuacos", haciendo alusión peyorativa al apoyo de los "negros" de Buenos Aires.

Si bien exceden el objetivo aquí expuesto, son notables otras innovaciones del controversial letrado, tales como el permanente uso de refranes y cielitos, o el particular uso de personajes alter-ego (principalmente femeninos) con quienes dialogaba creando efectos polifónicos: "Doña a Veces me Falta la Paciencia”, "Doña Detesta Niños", "Doña Honesta Recreación”, "Doña Lección no Interrumpida”, "Doña Estense los Cristos Quedos” o "Doña Mejor Jugador no Debe Quedar sin Cartas". También se destaca en el Desengañador Gauchi-Político, el uso del ícono autorreferencial de un franciscano degollado, conforme a su denuncia de persecuciones contra la libertad de expresión, que muestran sus innovaciones en el uso de la imagen como apoyo de la escritura impresa.

La comparación de adversarios políticos con ofidios y en términos generales, las alusiones al inframundo, fueron moneda habitual en su prosa, mezcladas con evocaciones al Quijote y otras referencias hispánicas. La figura del Averno, que vimos evocada en Pedro Miguel Aráoz, aparecía en el n. 13 del Desengañador, para deshumanizar al ya mencionado Miguel Estanislao Soler. El federal Soler, era duramente criticado tras su breve acceso a la gobernación de Buenos Aires, en un marco de militarización de la política: “¡Soler, Soler! ¡Monstruo infernal! ¡Vómito del Averno! ¿A qué empeñaros en aumentar el número de tus crímenes?” (Castañeda, n. ${ }^{\circ}$ 7, p. 223).

La animalización del gobernador de breve mandato, permitía al autor concluir que el federalismo era una enfermedad repleta de "pus" (Castañeda, n. ${ }^{2}$, pp. 29-32) ${ }^{10}$, o bien un monstruo reptil:

10 En este segundo número, el fraile además de criticar duramente al teatro porteño por incursionar en críticas al clero, agredía a adversarios con la metáfora de la "enfermedad federal". Sostenía que el ingreso de las tropas entrerrianas y santafecinas logró "envenenar a todo el mundo con la federación". Apuntaba nuevamente contra el pus federal del gaucho López, contra el chacuaco Ramirez, y también contra el putirepublicador, Carrera. 
El monstruo federación,

trae la piel color de sangre,

la cola brotando fuego,

y es preciso derribarle.

Mi señor Gauchi-político,

hoy un escuadrón ligero,

de matronas te convoca,

contra este animal tan fiero (Castañeda, n. ${ }^{\circ}$ 13, p. 316. El destacado

es nuestro) ${ }^{11}$.

La figura de la Hidra venenosa era usada en el mismo n. ${ }^{\circ} 13$ del Desengañador, esta vez para criticar al trasandino José Miguel Carrera, cercano al variado espectro federal. Al año siguiente, en simultáneo con el Desengañador Gauchi-Político, y también con Doña María Retazos, el literato franciscano comenzó De la Excma. e Ilma. Matrona comentadora de los 4 periodistas, en donde vuelve a valerse de la figura femenina para desarrollar una prosa compleja, abundante en la negación del adversario. En el n. ${ }^{\circ} 11$, el franciscano retoma la Hidra, a través de la voz ficticia de las matronas, sostenía que puesto que los enemigos eran múltiples, así también lo serían las polifónicas voces del periódico. Se presentó como novedad que la Hidra fuera utilizada como figura positiva, ya que sus voces al actuar en plural podían ser más poderosas. El uso de la multiplicidad de cabezas como una metáfora del bien, es sumamente llamativa, pero entronca con la singularidad de toda la obra de Castañeda y prueba el carácter polivalente de las imágenes grecolatinas y su variado recorrido territorial en el espacio rioplatense ${ }^{12}$.

11 La misma autora ficticia sugerida por el pseudónimo (la Matrona), publicaba y "firmaba" a continuación un cielito, que celebraba el triunfo ocurrido en Cañada de la Cruz, aunque no dejaba de advertir que el propio Estanislao fue un mal necesario. En el final del número, un nuevo recurso lingüístico permite a Castañeda sumar voces contra el "monstruo de la federación", y es el diálogo recreado entre un gaucho santafecino y uno porteño, festejando el triunfo de Estanislao del Campo.

12 El nuevo uso figurativo de las cabezas múltiples en Castañeda es el siguiente: "Los escritores en revolución son unos héroes que se baten con una hidra formidable, compuesta de tantas cabezas [...]. Aquí pues la razón: unámonos. Hagamos señuelo. Convoquemos a las matronas, pues sabemos que Dios las crio para enfrentar la furia [...]" Castañeda (4 de septiembre de 1821, pp. 473-474). 


\section{LAS ARMAS UNIDAS CONTRA EL MONSTRUO. LAS MEMORIAS DE JOSÉ MARÍA PAZ}

Dos de los textos de carácter autobiográfico más influyentes en la cultura política del siglo XIX rioplatense, fueron las memorias del general tucumano Gregorio Aráoz de Lamadrid (1795-1857), y la del cordobés, José María Paz (1791-1854), quienes pese a vincularse con la facción unitaria - o gracias a ello-, disputaron el honor de ubicarse como referentes de dicha identidad política. Sendos escritos que pretendieron erigirse como documentos probatorios de honestidad y heroísmo, ocasionaron una disputa por el recuerdo de la acción individual en una curiosa batalla por la memoria (Botana, 2007).

En el caso de Paz, comenzó sus escritos luego de su toma como prisionero en 1831. Más adelante, amplió su escritura a fin de consignar su participación en las campañas contra Juan Manuel de Rosas entre 1840 y 1846, publicándose sus memorias en 1855. Su estilo es directo, sin demasiadas referencias que pudiésemos considerar académicas, aunque hubo excepciones, compara a Manuel Belgrano (1770-1820), uno de sus modelos de virtud, con la tranquilidad de los cónsules romanos, apareciendo también mitos griegos y referencias a pensadores y pensadoras del temprano liberalismo europeo como Madame de Stäel (1776-1817). En sus apreciaciones sostenía que el carácter extenuante del proceso emancipatorio se debió a la desunión de la élite, que facilitó el reagrupamiento peninsular, ideas ya vistas en los sacerdotes analizados. Pese a las notorias diferencias con el lenguaje sobrecargado de los eclesiásticos, el líder unitario también se nutrió de categorías binarias. Aun contando con un manejo de las letras más rudimentario, el líder oriundo del interior rioplatense también apeló a las múltiples cabezas. Como ejemplo, en las páginas en las que explicaba el triunfo de Carlos María de Alvear en la toma de Montevideo (1814), el cronista desarrolla una reflexión que es recurrente en sus memorias. Luego de aquella entrada triunfal, garantizada por los triunfos marítimos del almirante irlandés Guillermo Brown (1777-1857), las tropas rioplatenses se confiaron en su suerte y alentaron la reagrupación adversaria, según su interpretación, de tipo cíclica. Se vivía un regocijo embriagador, ya que "todo el país creyó, y hasta los mismos enemigos, que la toma de Montevideo nos daba una superioridad decidida”. Sin embargo, 
evidenciando los males endémicos que lamentaba, pronto vinieron “divisiones y partidos" (Paz, 1855, pp. 188-190). En línea con la cultura política decimonónica, el general argumentaba que toda división era un elemento negativo. A modo de dotar de una representación visual a este clima apocalíptico, que se explicaba por los errores de Alvear y su fracción dirigente, se apoyaba en la conocida imagen de las cabezas regenerativas:

Una experiencia constante nos ha enseñado que el peligro solo reunía los ánimos y hacía esconder la cabeza a la anarquía, de modo que cuando nuestra situación parecía desesperada, un esfuerzo patriótico y unánime nos ha redimido del abismo. Por el contrario cuando nuestras victorias presentaban esperanzas las más lisonjeras, [...], se desencadenaban las pasiones, las facciones se agitaban convulsivamente, y nuestras propias divergencias volvían a sumirnos en el desorden [...] (Paz, 1855, pp.188-190).

En esa escritura un tanto caótica, pero con pretensiones de utilizar metáforas acuáticas inspiradoras, el general buscaba recursos para explicar los fracasos del grupo dirigente del cual había formado parte troncal. Sugiriendo una idea de lucha entre fuerzas, el hombre de armas sostenía que en situaciones dramáticas, un súbito gesto de "patriotismo" lograba dominar al adversario, y hacía esconder sus cabezas al monstruo de la Anarquía. En sentido inverso, pero en función de esta idea de balanza, sugería que en momentos en que todo parecía encaminado, las divisiones daban por tierra con los logros. En líneas siguientes, y pese a sostener que se trataba de una realidad compleja, adecuada para "plumas y talentos más ejercitados", el protagonista se preguntaba poéticamente si el resurgir de las pasiones era un mal intrínseco, o específico de la "sociedad argentina" (Paz, 1855, p. 189).

\section{Lo monstruoso del caudillismo en la generación romántica}

Retomando específicamente la alegoría de las múltiples cabezas, no es sorprendente que la pluma de Domingo Faustino Sarmiento (18111888) haya recurrido al preciosismo del lenguaje clásico en Facundo o civilización y barbarie en las pampas argentinas (1845). En cierto sentido la generación romántica rioplatense encarnaba ese ideal de "plumas y talentos más ejercitados”, que refería el general Paz en la cita del apartado 
anterior. Naturalmente, si Facundo Quiroga (1788-1835) era desde la pluma sarmientina un portador de "instintos feroces y sanguinarios", capaz de matar por puro placer, era plausible que el sanjuanino se dejara seducir por alegorías clásicas. En ese texto que constituye una de las joyas literarias decimonónicas, el enojo del caudillo Quiroga frente a algún evento político o incluso frente a algún malestar cotidiano, modificaba sus rasgos hasta hacerlo parecer una bestia, recurso potente que Sarmiento utilizaba acudiendo al corpus de la antigüedad clásica, con elementos del romanticismo europeo. Para lograr ese lenguaje telúrico y esa crítica que parecía esconder cierta admiración, rescataba de distintas provincias un conjunto de rumores que circulaban respecto a la naturaleza sobrenatural del líder federal (De la Fuente, 2007) ${ }^{13}$.

Así, Sarmiento sostenía que el caudillo "no conocía sujeción de ningún tipo", que "su cólera era la cólera de las fieras" y que en instancias de enojo "su voz se enronquecía y sus miradas se convertían en puñaladas". Con una adjetivación deshumanizante, y teniendo en cuenta los amplios conocimientos del escritor cuyano respecto al mundo clásico, era difícil no llegar a la utilización de la alegoría de las cabezas, tan extendida como vimos en diferentes suelos rioplatenses. Las extremidades venenosas, de hecho podían ser asimiladas como otro rasgo más de su "barbarie", teniendo en cuenta los pelos largos y ennegrecidos que verdaderamente usaba el joven caudillo:

La melena de sus renegridos y ensortijados cabellos caía sobre su frente y sus ojos, en guedejas como las serpientes de la cabeza de Medusa [...] Dominado por la cólera, mataba a patadas estrechándole los sesos a N. por una disputa de juego; arrancaba ambas orejas a su querida porque le pedía [...] 30 pesos para celebrar un matrimonio consentido por él [...] en todos los casos mostrábase el hombre, bestia aún (Sarmiento, 1868, p. 86. El destacado es nuestro).

Como es sabido, la crítica al caudillo de orientación federal implicaba además una crítica hacia la figura de Juan Manuel de Rosas,

\footnotetext{
13 Acerca del efecto de atracción que ejercía Quiroga sobre la población, se refieren diferentes testimonios de la época, como las memorias del general Paz, en donde se refiere su misticismo y conocida afición por la biblia, o el Facundo de Domingo Sarmiento, en el que se hace alusión a la creencia de que su caballo olía la muerte. Cabe destacar que el mencionado sacerdote Castro Barros, permanente generador de alegorías, fue uno de los formadores de este caudillo que sostendría el lema “¡Religión o muerte!”.
} 
quien también era en la obra sarmientina un "tirano", o simplemente un "monstruo". En la misma provincia de San Juan en donde creció el talentoso escritor, la prensa recurría mucho al tropo de las cabezas múltiples. En el periódico El Grito (1857), la línea editorial lamentaba lo que consideraba una persecución rosista contra figuras como Antonino Aberastain (1810-1861) y el sacerdote Justo Santa María de Oro (17721836), "que han comido largos años el pan del ostracismo en los años en que la Patria fue despóticamente vejada y maltratada por un tirano bárbaro y cruel (la Hidra de América)" (El Grito, 18 de junio de 1857, pp. 1-2). Nuevamente mostrando la ductilidad de la multiplicación de cabezas para distintos usos políticos, se advierte que el propio régimen rosista usó a su favor la mencionada alegoría, particularmente en la litografía titulada El exterminador de la anarquía. El tirano podía ser un restaurador de las leyes, y ser representado como Hércules frente a la Hidra o bien como la propia Hidra, mostrando en todos los casos la potencialidad del símbolo alegórico ${ }^{14}$.

El uso de imágenes caras a la sociedad rioplatense tampoco fue descuidado por Juan Bautista Alberdi (1810-1884), refiriéndose al aspecto seductor que podía tener el líder ganadero que tiranizaba a las provincias desde Buenos Aires según su interpretación. Es que precisamente, para el intelectual norteño, el "exterior de los perversos siempre fue atractivo". El joven Alberdi recordaba que en el mundo antiguo las bestias tenían un "bello rostro", como también enseñaba el ejemplo bíblico, ya que en definitiva "la tradición bíblica atribuye la perdición del mundo a la dulzura seductora de una serpiente" (Alberdi, 1900, p. 721).

Los integrantes del grupo romántico tuvieron considerables diferencias, pero un texto articulador fue el Dogma socialista (1873), escrito por Esteban Echeverría, con pasajes del propio Alberdi. Publicado por entregas desde el exilio montevideano, no sorprende aquí tampoco que la crítica al federalismo rosista refiera a los íconos clásicos. Ya en las primeras páginas aparece un uso de la Medusa, en las palabras dedicadas a los "mártires". Aquí se usa aquel recurso estilístico grecolatino, con una variante que vimos en Castañeda: el criticado era el rosismo, pero la imagen de la Hidra era utilizada en forma positiva para referirse a la resurrección permanente de referentes positivos. Así, las cabezas podían 
ser una imagen inquietante, pero en un mundo discursivo dual podían representar al Bien en su lucha contra el $\mathrm{Mal}^{15}$.

\section{CONGLUSIONES}

Teniendo como propósito ubicar la apropiación de la alegoría clásica de las cabezas múltiples, el presente trabajo sostiene el análisis de un amplio y variado corpus de usos de los mitos de la Medusa y de la Hidra en la pluma de letrados, publicistas y hombres de armas de las provincias rioplatenses, desde la década de 1810 hasta la organización constitucional conjunta ocurrida en 1853. En espacios geográficos que experimentaban la dificultad de dotar de institucionalidad política al orden político surgido de la revolución, la presente contribución al dossier incursiona en terrenos historiográficos novedosos y poco explorados para el área rioplatense, señalando un camino de diálogos con producciones que ubican el uso y sentido de estas alegorías en diferentes espacios del mundo atlántico, particularmente desde el siglo Xviri. En línea con estos estudios que han mostrado el notorio viraje político de estas narrativas que tenían otras funciones en el mundo greco-latino, la investigación sostiene que la notable recurrencia de la imagen de las cabezas regenerativas, indica la importancia de analizar los lenguajes políticos incorporando la alegoría como forma discursiva habitual, que permitía brindar entidad corpórea a binomios abstractos como el orden/desorden y el bien/ mal, presentándolos como una lucha cósmica o mítica. La ductilidad y plasticidad de estas narrativas antiguas, permitió a los actores sociales rioplatenses dotar de inteligibilidad a las transformaciones de su tiempo, e insistir en cada apropiación discursiva en distintos matices adecuados a los contextos de cada provincia, tales como el valor de la unidad, la arenga a favor de líderes que debían emular a Perseo y Hércules, así como argumentar en torno a conceptos de la época como la anarquía y las facciones. Para publicistas, referentes de la guerra o del mundo eclesiástico, la formación en cierta cultura clásica de fácil imbricación con la lectura bíblica, contenía ventajas como la legitimidad del lenguaje académico, la

15 La sugerente cita es la siguiente: "Desde el Paraná al Plata, desde el Plata a los Andes, desde los Andes al Chaco, corre el reguero de sangre de sus valientes; pero le quedan hijos y sangre, y ahí está de pie todavía, [...] desafiando al tirano argentino. ¿Qué pueblo como Corrientes en la historia de la humanidad? Un corazón y una cabeza que se reproducen como con nueva vida, como los miembros de la Hidra bajo el hacha exterminadora. [...]" (Echeverría, 1846, p. 14). 
arenga contra adversarios por vía cifrada, y en general, la búsqueda de impactar y persuadir a incipientes lectores de impresos y a la feligresía usando el golpe de efecto de narrativas potentes y duales.

Figura 3. Medusa con la Cabeza de Perseo

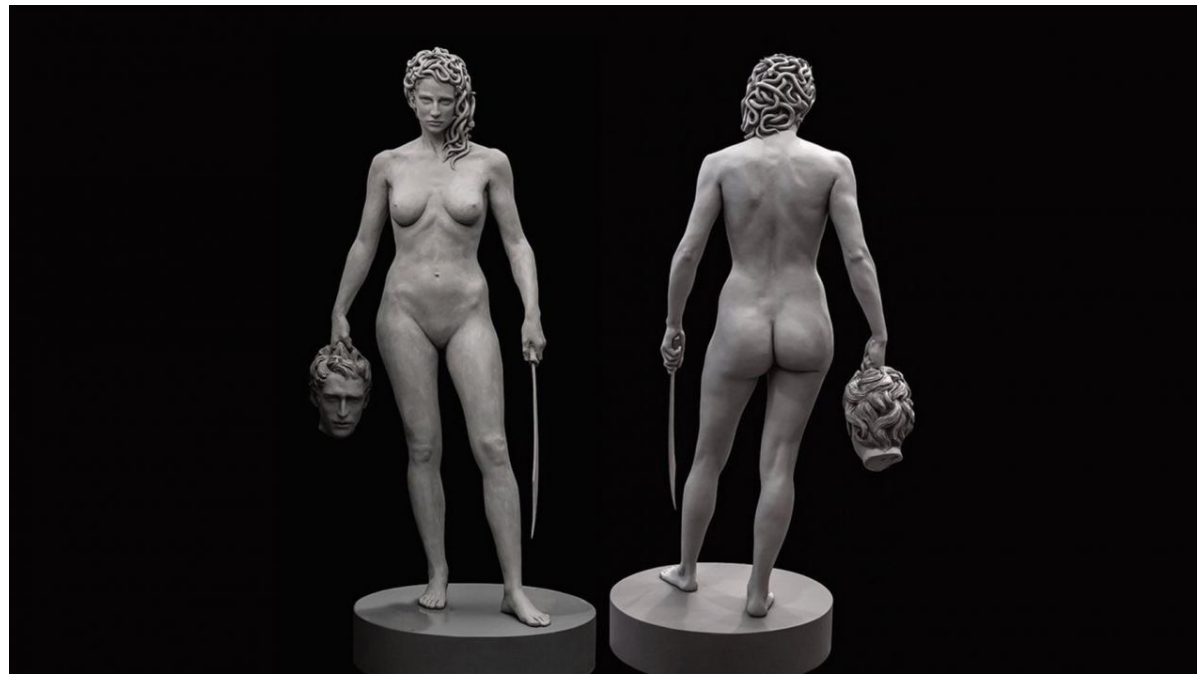

Fuente: Garbati (2018).

En particular, es notable el uso que las cabezas múltiples y el certero golpe mortal de los héroes tuvo en la década de 1820. Se han registrado y analizado estas apropiaciones dentro de sus contextos de enunciación en el texto, reponiendo en cada caso su relación con la cultura impresa y oral, con los climas de época y con la función apelativa con la que cada interlocutor buscó incidir en una esfera pública agitada por los cambios ocurridos desde la revolución.

Estas transformaciones políticas que podían ser representadas con la alegoría de las cabezas monstruosas, pero también con otras imágenes antiguas como las columnas de Hércules o las águilas imperiales, permiten visualizar la circulación común de ciertas narrativas en el espacio atlántico, aún lejos de la portuaria Buenos Aires. Para el fraile Castañeda, atento a erigir neologismos y aplicar ejercicios de estilo contra el federalismo y otros adversarios, pero también desde Tucumán para el cura Aráoz, la imagen de Perseo o Hércules venciendo a engendros múltiples, creaba herramientas conceptuales para abordar el complejo proceso de fragmentación de los espacios políticos ocurrida con la 
caída conjunta del Directorio, el Congreso y la Constitución de 1819. Asimismo, en el particular contexto del rosismo, la Hidra devoradora o la Medusa, en tanto mujeres de mirada petrificante, podían servir para demonizar a Juan Manuel de Rosas, o bien, para compararlo con Perseo o Hércules; denotando la recurrencia y plasticidad de estos símbolos tanto en Buenos Aires como en el interior de un territorio en construcción. Litografías, óleos, impresos, o arengas orales, han sido observados en geografías variadas como el área cuyana, la zona portuaria o los límites septentrionales de la confederación, mostrando que Rosas podía ser visto como un héroe o como un tirano, en línea con una vasta historiografía.

Desde una mirada de amplio alcance, la alegoría de las cabezas regenerativas, llegaba a Buenos Aires y al cono sur americano contando con siglos de circulación tanto en el continente europeo como en el americano. Así mismo, como símbolo del poder de las monarquías y luego, una vez ocurridas las independencias, como símbolo de los poderes locales, la alusión a Hércules o a Perseo funcionaba bien como alegoría de poder, pero siempre en advertencia contra el peligro de la ramificación del mal y del carácter huidizo de los monstruos. La firmeza y unidad del hacha frente a la replicación de las cabezas, es registrada por diferentes estudios en tierras tan distantes como Surinam, Buenos Aires, o las propias ciudades europeas, conectadas por una iconografía occidental que aún debe rastrearse, siendo este documento un aporte fundamental en tal dirección.

Por vía de textos como la Metamorfosis del romano Ovidio, la General Estoria de Alfonso X “el Sabio”, o mediante la simple transmisión oral, los publicistas americanos de las primeras décadas del siglo xIx pusieron en circulación la idea de la regeneración de las cabezas. Desde el ejemplo rioplatense, este elemento discursivo de las cabezas múltiples se adaptaba con ductilidad a una narrativa de tono político-moral, que sostenía una suerte de enseñanza frente a los opositores: cortar de raíz a los elementos que atentaban contra los gobiernos establecidos en la escala provincial y supra-provincial, en un contexto político signado por el gran interrogante de la institucionalización política y la organización conjunta del territorio.

En forma similar a lo que había ocurrido en la península ibérica con la asimilación de Napoleón Bonaparte y el monstruo bíblico de múltiples cabezas, la cultura rioplatense en este escenario enrarecido se valió de poderosas imágenes que permitían una imbricación entre la antigüedad clásica y la católica, apelando a soportes anclados en la profundidad de los sustratos culturales. Desde la prensa, el púlpito 
o la arenga militar, apelar a la moralidad de los héroes, contribuía a constituir una pedagogía política que negaba entidad al oponente, en un tiempo de complejas redefiniciones respecto a las formas de entender la soberanía y el acceso al poder. Apelando a aquel lenguaje clásico y católico, ya advertido por la historiografía rioplatense, el antagonista político era subsumido a una categoría reducida, incompatible con la vida cívica y, por lo tanto, imposible de asimilar al conjunto ciudadano, siendo así el nivel discursivo indispensable para entender las disputas rioplatenses. El carácter figurativo de las múltiples cabezas permitía un uso intencionado que recogía al mismo tiempo las ventajas de la supuesta objetividad y del encubrimiento por vía del lenguaje culto. Cuestionar al adversario mediante preciosismos del lenguaje permitía legitimar el propio lugar de enunciación, funcionando como forma correcta de cuestionar las facciones y apelando a lo clásico como puente cultural de relativo conocimiento para el exiguo público letrado.

\section{REFERENCIAS}

Alberdi, J. B. (1900). Escritos póstumos (tomo VIII). Imprenta europea.

Aráoz, P. (1820, 14 de octubre). El Tucumano Imparcial, n. 3 3, pp. 3-4.

Asociación Amigos Museo Histórico Cornelio de Saavedra. (s.f.). La paleta del Restaurador: Rosas y el rojo punzó. https://amigosdelmuseosaavedra.com.ar/ exposicion-temporaria/

Ayrolo, V. (2007). Funcionarios de Dios y de la República. Clero y política en la experiencia de las autonomías provinciales. Editorial Biblos.

Baltar, R. (2014). Francisco de Paula Castañeda: amanuense y autor. Cuadernos de Ilustración y Romanticismo: Revista Digital del Grupo de Estudios del Siglo XVIII, 20, 199-224. https://doi.org/10.25267/Cuad_Ilus_Romant.2014.i20.12

Bartra, A. (1984). Diccionario de Mitología. Grijalbo.

Beckles, H. (1984). Black Rebellion in Barbados: The Struggle Against Slavery, 16271838. Antilles Publications.

Blumenberg, H. (2000). La legibilidad del mundo. Ibérica.

Botana, N. R. (2007). Los ardides de la memoria: José María Paz entre la guerra y la revolución. Revista Escuela de Historia, 1(6), 3-15. https://www.redalyc.org/ pdf/638/63810602.pdf

Campbell, J. (1988). El poder del Mito. Emecé Editores.

Carranza, A. (1907). El clero argentino de 1810 a 1830. Museo Histórico Nacional. https://archive.org/details/elcleroargentin01archgoog/page/n412/ mode/2up?q=hidra

Castañeda, F. P. (1820-1822). El Desengañador Gauchi-Político, n. ${ }^{\circ}$ 2. https://archive. org/details/desengaadorgauch00cast/page/30 
Castañeda, F. P. (1820-1822). El Desengañador Gauchi-Político, n. ${ }^{\circ} 7$. https://archive. org/details/desengaadorgauch00cast/page/222

Castañeda, F. P. (1820-1822). El Desengañador Gauchi-Político, n. ${ }^{\circ}$ 13. https://archive. org/details/desengaadorgauch00cast/page/316

Castañeda, F. P. (1821, 4 de septiembre). De la Excma. e Ilma. Matrona comentadora de los 4 periodistas, n. ${ }^{\circ} 11$, pp. 473-474. https://archive.org/details/ damariaretazosde00cast/page/n277

De la Fuente, A. (2007). Los hijos de Facundo. Caudillos y montoneras en la provincia de La Rioja durante el proceso de formación del estado nacional argentino (1853-1870). Prometeo Libros.

Di Stefano, R. (2003). Lecturas políticas de la Biblia en la revolución rioplatense (1810-1835). Anuario de Historia de la Iglesia, (12), 201-224.

Di Stefano, R. (2004). El púlpito y la plaza. Clero, sociedad y política de la monarquía católica a la república rosista. Siglo XXI.

Echevarría, E. (1846). Dogma socialista. Imprenta del Nacional.

El Grito. (1857, 18 de junio). El Grito, n. ${ }^{\circ}$ 25, pp.1-2. San Juan Biblioteca del Museo Histórico Provincial "Agustín V. Gnecco".

Elíade, M. (1988). El mito del eterno retorno. Alianza Editorial.

Fernández-Ramos, J. C. (2015). Apuntes para una epistemología del análisis sociometafórico. Ariadna histórica. Lenguajes, conceptos, metáforas, (4), 11-64.

Gaune, R. (2018). Fisonomías y Morfologías de lo clásico. La autoridad clásica ante el Fatal casamiento de la Inexperta Doncella (Santiago, 1743). En N. Cruz \& M. Huidobro (Eds.), América Latina y lo clásico, lo clásico en América Latina. Universidad Andrés Bello.

Godicheau, F., \& Sánchez-León, P. (Eds.). (2015). Palabras que atan. Metáforas y conceptos del vínculo social en la historia moderna y contemporánea. Fondo de Cultura Económica.

Goldman, N. (2008). Lenguaje y revolución. Conceptos políticos clave en el Río de la Plata, 1780-1850. Prometeo Libros.

Goldman, N. (1998). Revolución, República y Confederación (1806-1852) (Tomo III). Editorial Sudamericana.

Herrero, F. (1999). Indicios y estrategias. Lucha por el poder en Buenos Aires durante el crítico año de 1820. Prohistoria: historia, políticas de la historia, (3), 111-132.

Herrero, F. (2012). La idea de independencia durante los días de la Revolución americana y de la Restauración europea. El difícil sermón patriótico de Francisco Castañeda en la Catedral de Buenos Aires. Iberoamericana. América Latina, España, Portugal, 12(45), 59-79. https://www.jstor.org/stable/41677558

Herrero, F. (2018). Política, práctica asociativa, formas de comunicar. La experiencia de un caso en Buenos Aires en el contexto de la revolución. Illes $i$ Imperis, (20), 153-177. https://doi.org/10.31009/illesimperis.2018.i20.07

Herrero, F. (2020). El fraile Castañeda. ¿El "trompeta de la discordia”? Intervenciones públicas, de Mayo a Rosas. Prometeo Libros.

Martínez-Paz, E. (1940). Plan de Estudios para la Universidad Mayor de Córdoba. Año 1813. Biblioteca Nacional. 
Mitchell, W. J. (2016). Iconología. Imagen, texto, ideología. Editorial Capital Intelectual.

Morín, A. (1999). La Medusa como imagen de pecado en la Edad Media. Revista Incipit, (19), 186-206.

Myers, J. (1995). Orden y Virtud. El discurso republicano en el régimen rosista. Universidad Nacional de Quilmes.

Nanni, F. (2017). Grupos políticos y facciones en la construcción de la provincia de Tucumán. 1814-1841. Revista Polhis (19), 4-49.

Palti, E. J. (2007). El tiempo de la política. El siglo XIX reconsiderado. Siglo Xxi Editores.

Paz, J. M. (1855). Memorias Póstumas del Brigadier General Don José María Paz. Editorial Imprenta de la Revista.

Peire, J. (2000). El taller de los espejos: iglesia e imaginario (1767-1815). Editorial Claridad.

Polastrelli, I. (2017). Castigar los crímenes de la anterior administración. El juicio contra los miembros del Directorio y del Congreso en 1820. Anuario del Instituto de Historia Argentina, 17(2), 1-16. http://hdl.handle.net/2133/16306 https://doi.org/10.24215/2314257Xe054

Ramón-Solans, F. J. (2017). La hidra revolucionaria. Apocalipsis y antiliberalismo en la España del primer tercio del siglo xıx. Hispania, 77(256), 471-496. https://doi.org/10.3989/hispania.2017.014

Rediker, M., \& Linebaugh P. (2000). The Many-Headed Hydra. Sailors, Slaves, Commoners, and the Hidden History of the Revolutionary Atlantic. Beacon Press. https://doi.org/10.1177/084387140101300212

Rodríguez, C. (2008). Correspondencia con el doctor José Agustín Molina (1812-1820). Academia Nacional de la Historia.

Rousseau, J. J. (1762). Du Contrat Social, ou principes du droit politique. Union Générale d'Éditions.

Sanfuentes, O. (2016). La utopía de un imperio católico universal. Análisis iconográfico e iconológico del frontispicio de una crónica americana del siglo Xvı: Elegías de hombres ilustres de Indias de Juan de Castellanos. Quintana. Revista de Estudios do Departamento de Historia da Arte, (15), 1529. https://www.redalyc.org/pdf/653/65354336003.pdf https://doi. org/10.15304/qui.15.4506

Sarmiento, D. (1868). Facundo o civilización y barbarie en las pampas argentinas. Hachette y Cia.

Terán, C. (2008). El retrato en Tucumán antes del siglo XIX. Edunt.

Ternavasio, M. (2004). Construir poder y dividir poderes. Buenos Aires durante la 'feliz experiencia' rivadaviana. Boletín del Instituto de Historia Argentina y Americana Dr. Emilio Ravignani, 26, 7-43. http://ravignanidigital.com.ar/_bol_ ravig/n26/n26a01.pdf

Vignolo, P. (2012). Más allá de las columnas de Hércules: un emblema de Modernidad temprana. En M. Hering \& A. Pérez (Eds.), Historia Cultural desde Colombia. Categorías y Debtes, (pp. 139-164). Ediciones Universidad Nacional de Colombia. 
Voltaire (1751). Le Siècle de Louis xıv. Ed. Charles Louandre.

Wasserman, F. (Comp.). (2019). El mundo en movimiento. El concepto de revolución en Iberoamérica y el Atlántico norte (siglos XVII-XX). Miño y Dávila Editores.

Zeballos, E. S. (1902). Poesías del Ilustrísimo Obispo de Camaco doctor José Agustín Molina. Revista de Derecho, Historia y Letras, 4(XII), 99-105. 